\title{
Microbiological surveillance of air and contact surface of pubic transports with its correlation to human infection risks
}

\author{
Shah Murshid Uj Jaman Arowan, Kamal Kanta Das and Farahnaaz Feroz* \\ Department of Microbiology, Stamford University Bangladesh, 51, Siddeswari Road, Dhaka-1217, Bangladesh
}

Received 28 July 2021/Accepted 01 September 2021

\begin{abstract}
Over past few years, people are giving more attention to air pollution and its effects on human health. Due to the high population density in Bangladesh, air pollution is a major issue in metropolitan areas, especially in Dhaka city. Present study aims to isolate air-borne microbes from the inside environment of public transport and different types of microbes that are frequently encountered by commuters when they touch the interior surfaces of vehicles used for public transport in Dhaka City. Atmospheric load of microorganisms was measured with petri dish which was kept open for 30 minutes in the sampling locations and swabs were taken from interior surfaces of vehicles. Air samples collected from both bus and railway stations showed a high atmospheric microbial count (total viable bacteria and total fungal count were 140 to $776 \mathrm{CFU} / \mathrm{plate} / 30 \mathrm{~min}$ and 27 to $168 \mathrm{CFU} / \mathrm{plate} / 30 \mathrm{~min}$, respectively). A similar outcome was found after analysis of swab samples of the contact surfaces of the vehicles as well. A total of four bacterial pathogens were identified from the interior surfaces of the vehicle including Escherichia coli, Bacillus spp., Pseudomonas spp. and Vibrio spp. which are known to be associated with gastrointestinal tract infection. To manage and control the environmental health risks caused by air pathogens, an authorized governmental agency should do continuous monitoring of air quality to reduce the negative effects and impacts of air pathogens on human and animal health. This research has shown a great concern to health practitioners in developing countries because these are pathogens that are mostly resistant to the commonly available antibiotics used in the treatment of infection associated with these pathogens. Most importantly, we need to raise awareness among the public in order to reduce the load and spread of pathogenic bacteria in the environment.
\end{abstract}

Keywords: Air quality, Environmental pollution, Public transport, Personal hygiene.

\section{INTRODUCTION}

Over the last 20 years, maintaining the deteriorating air quality of open areas has become a challenging matter $(1,2)$. World are now giving more attention to the severe health effects, which is caused by the open area air pollution (3). The United States Environmental Protection Agency (USEPA) has also agreed that, the amount pollutant of open area is 100 times greater comparing to indoor areas (4). Microorganisms are easily transported from one area to another as bio aerosols or droplet via wind or human activities such as, sneezing, coughing or laughing, as a result the spread of disease causing agents to human hosts have become more convenient (5). Generally Pathogenic microbes cause infections upon entry into susceptible host via skin, food, water, breathing and other interpersonal contact (6).

Many respiratory diseases like allergies, asthma, upper and lower respiratory tract infections are caused by pathogenic microorganisms present in airborne particles. Such contaminated particles can act as infectious agents (7). Transportation of these infectious agents can progress very swiftly from one host to another through direct and indirect routes of transmission (8). Many studies have suggested that we could suggest some precautionary steps to prevent the extensive contamination of fungi and bacteria depend mainly on seasonal environment and climatic factors, such as temperature, air moisture and time of day, wind speed and direction, existence of human activity and type of ventilation in closed spaces (9). Furthermore need to identify the factors such as are temperature, humidity, concentration of hydrogen ions in the environment, oxidation reduction or water activity of the environment can stimulate the growth and devolvement fungal and bacterial contamination of environments (10). This will also help to detect the fungal and bacterial particles in the open air (11). Most of these bacteria and fungus are often shed from human skin surfaces (12). It is not surprising to find thousands of bacteria per grams of dust on the floor (4). Moreover, different enteric bacteria like Escherichia coli, Klebsiella spp. and Staphylococcus spp. with spore forming bacteria like Bacillus subtilis and B. cereus are most common in outdoor area (13). In open area, spores of molds and bacteria are generally stays in the air and they can gradually spread due to turbulence in air (14). Many of them are released by coughing or sneezing by Human and animals likewise open dustbin, plant, soil, wastebasket etc. have some contribution in air pollution (15). If we study the negative impact of airborne microbes, then adverse effects on health and economic loss. In 
Bangladesh we can use diverse cleaning and disinfectant like bio aerosols such as, fungicides and bactericides to destroy environmental microorganisms as all other developed and under developed countries do (16). In last 10 years the use of fungicides and bactericides has met some negative attitudes of the consumer, due to their harmful effect on human health. It is necessary to improve the environmental condition by reducing the air pollution through improved management of waste (17).

Bus and Railway station areas are complex environments for mass transit which need proper attention for public health and control of environmental wastes (18). Use of some suitable techniques like passive sedimentation can be used for determining microbiological load for creating and alert (4). Automated techniques are also useful for quantitative analyses of bio burden in air (19). To manage and control environmental health risks, such as air pathogens, we need to continue research focusing on the effect and impacts of air pathogens on human and animal health (20). Considering the high population density in Bangladesh and its impact of air contamination, the present study aims to isolate airborne microbes from public transport areas and identify the type of microbes found on the surface of public transport vehicles in Dhaka City.

\section{MATERIALS AND METHODS}

Sampling Areas. Air sampling was carried out at Saidabad bus terminal, Gabtoli bus terminal, Gulisthan bus terminal, Kamalapur railway station, Narayanganj railway station and Tongi railway station during November and December 2018. Automobile interior surface organisms were collected from the steering, bus handle, seat back and seat handle. The atmospheric microorganisms were collected from Saidabad bus terminal, Gabtoli bus terminal, Gulisthan bus terminal, Kamalapur railway station, Narayanganj railway station and Tongi railway station.

Measuring the atmospheric microorganisms. Atmospheric microorganisms were measured on agar plates using settle plate technique (20). Mainly two types of agar media were used in this experiment nutrien agar (NA) media for bacterial growth and Sabouraud Dextrose Agar (SDA) media for fungal growth. The petri dish was kept open for 30 minutes in the sampling locations, to collect microorganisms. They were placed at three different locations at each sampling area, to gather an average count of organisms present. After collecting the air samples, the media plates were incubated for 24 hours at $37^{\circ} \mathrm{C}$ for bacterial growth (NA) and 48 hours at $25^{\circ} \mathrm{C}$ for fungal growth (SDA). Visible colonies were counted after incubation to determine the load of microorganisms (22).

Identification of contact surface microorganisms from interior surfaces of automobiles. Nutrient Agar (NA), Sabouraud Dextrose Agar (SDA) Mannitol Salt Agar (MSA), McConkey Agar (MAC), Starch agar, Pseudomonas agar, Thiosulfate-Citrate-Bile Salts-Sucrose (TCBS) and Xylose Lysine Deoxycholate (XLD) agar media were used to identify bacterial growth count, fungal growth count, Staphylococcus spp., E. coli and Klebsiella spp., Bacillus spp., Pseudomonas spp., Vibrio spp. Salmonella spp. and Shigella spp. count, Respectively. Cotton swab was used to collect surface sample after moistening with $0.85 \% \mathrm{NaCl}$ solution. After collecting samples the cotton swabs were stored into nutrient broth (NB) during transportation, within one hour samples were transfer to the lab and soon all the samples were inoculated on specific media. This experiment was performed to detect how many microorganisms are present in the surface of the steering wheel, bus handle, seat back, seat handle area. All the media plates were incubated for 24 hours at $37^{\circ} \mathrm{C}$ for bacterial growth and 48 hours at $25^{\circ} \mathrm{C}$ for fungal growth (SDA). The presence of colonies were counted and for further confirmation bacteria were determined by using biochemical tests such as TSI-Triple Sugar Iron test, VP (Voges Proskauer) test, MR (Methyl Red) test, Indole, Catalase, Oxidase, Citrate test according to Bergey's Manual of Bacteriology $(21,23)$

\section{RESULTS}

The table 1 describes the total microbial count and total fungal count of atmospheric microorganisms in different places, which was collected by settle plate technique for 30 minutes. Table 1 shows bus station areas including Saidabad bus terminal, Gabtoli bus terminal and Gulisthan bus terminal area had higher number of bacterial and fungal colonies. Railway station such as Kamalapur railway station, Narayanganj railway station, Tongi railway station area had comparatively lower number of bacterial and fungal count. Saidabad bus terminal area had $776 \mathrm{CFU} /$ plate/30 minutes of bacterial growth and $168 \mathrm{CFU} /$ plate/30 minutes of fungal growth. Gabtoli bus terminal area had $213 \mathrm{CFU} /$ plate/30 minutes bacterial and $27 \mathrm{CFU} /$ plate/30 minutes fungal colonies present; Gulisthan bus terminal area had 272 CFU/plate/30 minutes bacterial and 69 CFU/plate/30 minutes fungal colonies present.

As seen in Table 1, Railway station area had lower number of atmospheric bacterial and fungal count. In other areas, Bus station area had higher number of bacterial and fungal colonies present. Such as, Kamalapur station area had $205 \mathrm{CFU} /$ plate/30 minutes bacterial and $58 \mathrm{CFU} /$ plate/30 minutes fungal colonies; Narayanganj station area had 140 CFU/plate/30 minutes bacterial and 112 $\mathrm{CFU} /$ plate/30 minutes fungal colonies; Tongi station area had $180 \mathrm{CFU} /$ plate/30 minutes bacterial and 98 $\mathrm{CFU} /$ plate/30 minutes fungal colonies.

From the automobile interior surfaces, presence of bacteria was recorded on Table 2. Eight different media plates were used to detect microbial growth. The steering wheel, bus handle, seat back and seat handle result was significantly high bacterial growth, while medium fungal growth was observed for seat back and seat handle. Escherichia coli, Pseudomonas spp. and Staphylococcus spp. were predominantly observed in most of the case. On the other hand, Bacillus spp. and Vibrio spp. were only found in the steering and seat handle. Salmonella spp. and Shigella spp. were found to be absent in all automobile interior surface observed (Table 3). 
Table 1. Falling organism at different location Dhaka city.

\begin{tabular}{|c|c|c|c|}
\hline \multirow[t]{2}{*}{ Location } & \multirow[t]{2}{*}{ Areas } & \multicolumn{2}{|c|}{$\begin{array}{l}\text { Falling microorganisms } \\
\text { (CFU/plate/30 minutes) }\end{array}$} \\
\hline & & Total Viable Bacteria & Total Fungi \\
\hline \multirow{3}{*}{ Railway station } & Kamalapur station & 205 & 58 \\
\hline & Narayanganj station & 140 & 112 \\
\hline & Tongi station & 180 & 98 \\
\hline \multirow{3}{*}{ Bus station } & Saidabad terminal & 776 & 168 \\
\hline & Gabtoli terminal & 213 & 27 \\
\hline & Gulisthan terminal & 272 & 69 \\
\hline
\end{tabular}

Table 2. Presence of pathogens in vehicle interior surfaces.

\begin{tabular}{|c|c|c|c|c|c|c|c|c|}
\hline \multirow{2}{*}{$\begin{array}{l}\text { Samples } \\
\text { Area } \\
\end{array}$} & \multirow{2}{*}{$\begin{array}{c}\text { No of } \\
\text { samples }\end{array}$} & \multicolumn{6}{|c|}{ No. of positive case (percentage) } & \multirow[b]{2}{*}{ Vibrio spp. } \\
\hline & & TVBC & Fungi & E. coli & Staphylococcus spp. & Bacillus spp. & Pseudomonas spp. & \\
\hline Bus Steering & 5 & $5(100 \%)$ & $3(60 \%)$ & $3(60 \%)$ & $4(80 \%)$ & $1(20 \%)$ & $4(80 \%)$ & $2(40 \%)$ \\
\hline Bus handle & 5 & $5(100 \%)$ & $3(60 \%)$ & $3(60 \%)$ & $4(80 \%)$ & 0 & $4(80 \%)$ & 0 \\
\hline Seat back & 5 & $5(100 \%)$ & $2(40 \%)$ & $1(20 \%)$ & $2(40 \%)$ & 0 & $4(80 \%)$ & 0 \\
\hline Seat handle & 5 & $5(100 \%)$ & $2(40 \%)$ & $5(100 \%)$ & $4(80 \%)$ & $2(40 \%)$ & $4(80 \%)$ & $2(40 \%)$ \\
\hline
\end{tabular}

Table 3. Confirmative biochemical tests for the isolates.

\begin{tabular}{|c|c|c|c|c|c|c|c|c|c|c|}
\hline \multirow{2}{*}{$\begin{array}{l}\text { Assumed } \\
\text { Organism }\end{array}$} & \multicolumn{3}{|c|}{ TSI } & \multirow{2}{*}{ 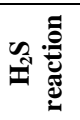 } & \multirow{2}{*}{ 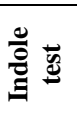 } & \multirow[b]{2}{*}{$\sum \stackrel{\vec{a}}{\stackrel{a}{*}}$} & \multirow{2}{*}{$\frac{\vec{s}}{\dot{s}}$} & \multirow{2}{*}{ 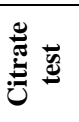 } & \multirow{2}{*}{ 总 } & \multirow{2}{*}{ 总 } \\
\hline & $\vec{\Xi}$ & $\underset{\Xi}{\Xi}$ & שี & & & & & & & \\
\hline Escherichia coli & $\mathrm{Y}$ & $\mathrm{Y}$ & + & - & - & - & - & + & + & - \\
\hline Pseudomonas spp. & $\mathrm{Y}$ & $\mathrm{Y}$ & + & + & - & + & - & + & + & + \\
\hline Staphylococcus spp. & $\mathrm{Y}$ & $\mathrm{Y}$ & - & - & - & - & - & + & + & - \\
\hline Bacillus spp. & $\mathrm{Y}$ & $\mathrm{Y}$ & - & - & - & - & + & + & + & ND \\
\hline Vibrio spp. & $\mathrm{Y}$ & $\mathrm{Y}$ & - & - & + & + & - & + & ND & + \\
\hline Salmonella spp. & $\mathrm{R}$ & $\mathrm{Y}$ & - & + & - & + & - & - & + & - \\
\hline
\end{tabular}

\section{DISCUSSION}

Microbes can be found on all surfaces, in the air, on plants, in water and on the human body, with humans serving as a major source, especially in indoor environments $(24,26,27)$. When human occupants are larger in number, they have a more significant impact on the number of microbes present in the air (28). For this purpose, the current study attempted to identify the presence of microbes on public transport in Dhaka city and its impact on the travelers. Bus station area contains higher surface bacterial load than the railway station area. Atmospheric organisms count of both bus station and railway station areas demonstrated higher bacterial growth than fungal growth. This could be a result of bus station area possessing more contamination points than the railway station area. Observations of contamination on vehicle interior surface samples revealed the microbial presence on the steering wheel, bus handle, seat back and seat handle to be. Therefore, it may be inferred that the surface of the public transport are not microbiologically safe for the public, precautions must be set in place to ensure the health of the citizens. The bacteria in the environment can influence human health $(29,30)$. To control the infections related to air several methods could include attempts to decontaminate the air or the interior surface need to apply by government and citizens to protect themselves.

As mentioned in Table 2, Escherichia coli and a gastrointestinal pathogen like Vibrio spp. found on interior of bus are the causative agent of gastrointestinal problem similar bacillary dysentery in most developing countries today, which is fatal in children if not diagnosed and treated on time $(4,17$, 30). Due to the presence of such bacteria on the steering, bus handle, seat back and seat handle areas should be monitored and maintained regularly, which may involve setting up systems to the clean and ensure hygienic conditions, and enforcing rules very strictly in order to prevent the spread of contaminating agent in the food cycle and other areas. This is particularly alarming as many passengers eat while transporting or immediately after transport without cleaning their hands properly. The results of the current study show similar results as reported by Badri et al., (2014), in terms of bacterial and fungal growth (4). They reported the presence of 
microorganisms inside some dwellings in Bagdad city. Their results showed NA agar media for bacterial count having high growth in maximum indoor area, the MAC agar media coliform bacteria count shows low growth in maximum indoor area. Conversely, the results of the current study, as shown in Table 1, for all six palaces shows high growth in both indoor and outdoor spaces.

A more comprehensive report on the air quality of Dhaka City may have been provided in this study, if more sampling locations, including a wider range of categories such as hospitals and restaurants, were used. Further experiments to identify the specific pathogenic microbes from air environment of different places in Dhaka city are required to analyze the air quality and to ensure the safety of the citizens. In addition, the bacteria isolated here by swab, were introduced from the skin and respiratory tract of human which release through shedding off from skin, sneezing or talking also from soil and water. Therefore, the microorganisms isolated from the sampling sites were contributed by human and the outdoor environment. Determining the presence of organisms in air and surface of vehicle interior can be used to take some precautionary steps like generate low amount of waste, development of well waste management system to prevent the spread of harmful microorganism from our open environment and vehicle interior surface. By preventing the spread of these microbes at least we could protect peoples from harmful disease-causing microbes. Along with this, social awareness by governmental or non govt. organizations can procure a healthy and peaceful life.

\section{CONCLUSION}

In summary, the mode of transmission of microorganisms mainly pathogenic microbes can transfer hands to surfaces in a public lavatory setting can cause different infections. Our data suggest control of microbiological quality of the air and touch surface areas of public places significant parameter to control healthcare associated infections of mass of peoples also we can prevent the person to person transmission of different contagious diseases from via cleaning of contact surfaces in public areas as well as in households.

\section{REFERENCES}

1. Leung DYC. 2015. Outdoor indoor air pollution in urban environment: challenges and opportunity. Fron. Env. Sci. 2(69):1-7. Pavan R and Manjunath K. 2014. Qualitative Analysis of Indoor and Outdoor Airborne Fungi in Cowshed. J. Mycol. 2014(985921):1-8.

3. Qudiesat K, Abu-Elteen K, Elkarmi A, Hamad M and Abussaud M 2009. Assessment of airborne pathogens in healthcare settings. Afr. J. Microbiol. Res. 3(2):066-076.

4. Badri M. 2014. Identification and Characterization of Bacteria Air Pathogens from Homes in Some Areas of the Baghdad City. Int. J. Adv. Res. 2(6):384-388.

5. Eze EI, Echezona BC and Uzodinma EC. 2011. Isolation and identification of pathogenic bacteria associated with frozen mackerel fish (Scomber scombrus) in a humid tropical environment. Afr. J. Agric. Res. 6(8):1947-1951.

6. Yassin MF and Almouqatea S. 2010. Assessment of airborne bacteria and fungi in an indoor and outdoor environment. Int. J. Environ. Sci. Technol. 7(3):535-544.

7. Cordeiro RA, Brilhante RSN, Pantoja LDM, Filho REM, Vieira PRN, Rocha MFG et al. 2010. Isolation of pathogenic yeasts in the air from hospital environments in the city of Fortaleza, northeast Brazil. Braz. J. Infect. Dis. 14(1):30-34.

8. Mei S, Chen B, Zhu Y, Lees MH, Boukhanovsky AV and Sloot PMA. 2015. Simulating city-level airborne infectious diseases. Comput. Environ. Urban Syst. 51:97-105.

9. Polymenakou PN. 2012. Atmosphere: A Source of Pathogenic or Beneficial Microbes? Atmosphere 3(1):87-102.

10. Chen M, Wang C, Fei B, Ma X, Zhang B, Zhang S et al. 2017. Biological Degradation of Chinese Fir with Trametes versicolor (L.) Lloyd. Materials 10:834

11. Eames I, Tang JW, Li Y and Wilson P. 2009. Airborne transmission of disease in hospitals. J. R. Soc. Interface 6:S697-S702.

12. Aliabadi AA, Rogak SN, Bartlett KH and Green SI. 2011. Preventing Airborne Disease Transmission: Review of Methods for Ventilation Design in Health Care Facilities. Adv. Prev. Med. 2011:124064.

13. Reanprayoon P and Yoonaiwong W. 2012. Airborne concentrations of bacteria and fungi in Thailand border market. Aerobiologia 28:4960 .

14. Gray WB and Shimshacky JP. 2011. The Effectiveness of Environmental Monitoring and Enforcement: A Review of the Empirical Evidence. Rev. Env. Econ. Policy. 5(1):3-24.

15. Bergen BJ, Nelson WG, Mackay J, Dickerson D and Jayaraman S. 2005. Environmental Monitoring of Remedial Dredging At The New Bedford Harbor, Ma, Superfund Site. Environ. Monit. Assess. 111:257-275.

16. Fennelly KP, Davidow AL, Miller SL, Connell N and Ellner JJ. 2004. Airborne Infection with Bacillus anthracis-from Mills to Mail. Emerg. Infect. Dis. 10(6):996-1001.

17. Fernstrom A and Goldblatt M. 2013. Aerobiology and Its Role in the Transmission of Infectious Diseases. J. Pathog. 2013(493960):1-13.

18. AbeAyotunde S, Bashir I, Habibu A, Aliyu MS, Hauwa AM and Mohammed G. 2012. Identification and Characterization of Bacteria Air Pathogens from Homes in Zaria Metropolis. Int. J. Sci. Technol. 2(7):443-446.

19. Fang Z, Ouyang Z, Zheng H and Wang X. 2008. Concentration and Size Distribution of Culturable Airborne Microorganisms in Outdoor Environments in Beijing, China. Aerosol. Sci. Technol. 42(5):325334.

20. Soto T, Lozano M, Vicente-Soler J, Cansado J and Gacto M. 2009. Microbiological survey of the aerial contamination in urban areas of the city of Murcia, Spain. An Biol. 31:7-13.

21. Cappuccino JG and Sherman N. 1996. Microbiology - A Laboratory Manual. Benjamin/Cummings Publishing Co., Inc., Menlo Park, California.

22. Prathab AG and Lalitha C. 2012. Microbiological surveillance of air quality in operation theatres - comparison of the conventional settle plate techniques vs use of an air sampling device. J. Evol. Med. Dent. Sci. 1(4):371-381.

23. Buchanan RE and Gibbons NE. 1974. Bergey's Manual of Determinative Bacteriology, $8^{\text {th }}$ edition, The Williams and Wilkins Company, Baltimore.

24. Adams RI, Bateman AC, Bik HM and Meadow JF. 2015. Microbiota of the indoor environment: a meta-analysis. Microbiome. 3:1-18.

25. Adams RI, Bhangar S, Pasut W, Arens EA, Taylor JW, Lindow SE et al. 2015. Chamber bioaerosol study: outdoor air and human occupants as sources of indoor airborne microbes. PLoS One 10:e128022.

26. Alam MS, Feroz F, Rahman H, Das KK and Noor R. 2015. Microbiological contamination sources of freshly cultivated vegetables. Nutr. Food Sci. 45(4):646-658.

27. Rahman H, Feroz F, Alam MS, Das KK and Noor R. 2016. Demonstration of the source of microbial contamination of freshly cultivated cabbage, cauliflower, potato and squash collected from rural farms of Bangladesh. Int. Food Res. J. 23(3):1289-1295.

28. Fox A, Harley W, Feigley C, Salzberg D, Toole C, Sebastian A et al. 2005. Large particles are responsible for elevated bacterial marker levels in school air upon occupation. J. Environ. Monit. 7:450-456.

29. Rahman MM, Das KK, Aktar K and Feroz F. 2020. Isolation and screening of dye degrading microorganisms from industrial waste of Dhaka city. Asian J. Microbiol. Biotechnol. Environ. Sci. 22(3):535540

30. Flandroy L, Poutahidis T, Berg G, Clarke G, Dao M, Decaestecker E et al. 2018. The impact of human activities and lifestyles on the interlinked microbiota and health of humans and of ecosystems. Sci. Total Environ. 627:1018-1038 